\title{
PLASMAPHERESIS AS PREPARATORY METHOD FOR THYMECTOMY IN MYASTHENIA GRAVIS
}

\author{
JOSÉ CARLOS BRANT SEGGIA*, PAULO ABREU**, M. TAKATANI***
}

\begin{abstract}
SUMMARY - To study the effects of plasmapheresis in preparation for thymectomy, two groups of 40 patients were selected from a sample of 286 patients with myasthenia gravis examined by the first author Group 1 included patients ( 15 male and 25 female; age range 8-64 yrs) who underwent thymectomy without previous plasmapheresis, whereas patients in group 2 (17 male and 23 female; age range 11-61 yrs) were thymectomized after plasmapheresis. We required patients to have a minimum follow-up period of 12 months to be included in the study. A clinical evaluation protocol composed of 76 items was developed for the study. We found significant improvement in respiratory function and muscular strength in patients thymetomized after plasmapheresis. Furthermore, the combined treatment reduced cost and length of hospital stay. Therefore, we conclude that plasmapheresis should be considered as a coadjuvant to thymectomy in the treatment of myasthenia gravis.
\end{abstract}

KEY WORDS: myasthenia gravis, thymectomy, plasmapheresis.

Plasmaferese como método preparatório de timectomia em miastenia grave

RESUMO - No intuito de estudar as repercussões de um curso de plasmaferese como método preparatório para a timectomia, tomamos duas amostras de 40 pacientes selecionados de um universo de 286 casos de miastenia gravis, em que a investigação clínica, eletrofisiológica, laboratorial, o seguimento e o protocolo foram completamente realizados. Considcramos como grupo 1 aquele em que a timectomia foi realizada sem preparação pre-operatória e grupo 2 aquele em que a plasmaferese foi executada como coadjuvante a timectomia. 0 grupo 1 era composto de 15 pacientes do sexo masculino e 25 do feminino; a idade variou de 8 a 64 anos com mediana de 30 anos. No segundo grupo, 17 eram masculinos e 23 femininos; a idade variou de 11 a 61 anos com mediana de 33 anos. Foi preenchida ficha de avaliação clínica sequencial de 76 itens e traçamos um curso de plasmaferese de 5 sessões seguido da timectomia, mantendo a mesma técnica operatória, realizada pela mesma equipe cirúrgica, tentando assim minimizar as distorçōes na análise e manuseio destes pacientes. Obtivemos melhora clínica, da insuficiência respiratória, da força muscular e reduzimos também o custo da internaçāo quando comparada aos pacientes em que a cirurgia foi realizada sem a plasmaferese $\mathrm{e} \mathrm{em}$ alguns casos $\mathrm{em}$ que realizamos preparação com corticosteróides. Acreditamos que a plasmaferese deva ser considerada como método coadjuvante no tratamento cirúrgico desta grave afecçāo.

PALAVRAS-CHAVE: miastenia gravis, timectomia, plasmaferese.

Myasthenia gravis (MG) is a disease of the neuromuscular junction characterized by weakness and abnormal fatigue in the skeletal muscles. It was first described by Thomas Willis in 1672. However, a more precise clinical account of this disorder was offered by Campbell and Bramwell in $1900^{4}$. In 1901, Oppenheim hypothesized that MG was a disease of the neuromuscular junction by analogy with symptoms of curare poisoning ${ }^{21}$. Several ciinical aspects suggest that the basic defect of $M G$ is an antibody-mediated autoimmune attack of the neuromuscular junction, as for example:

Hospital dos Servidores do Estado, Rio de Janeiro, Brasil: *Head of Clinic of the Neurologic Clinic; **Staff member of the Nephrology Clinic; ${ }^{* * *}$ Resident at the Neurologic Clinic. Aceite: 7-fevereiro-1995. 
(1) fluctuating course; (2) association with other diseases of known autoimmune etiology; (3) increase in the levels of autoantibodies; (4) increased frequency of HLA epitopes and markers for the heavy chain of immunoglobin; (5) clinical improvement with immunosuppressing drugs or following plasmapheresis. In 1960, Simpson ${ }^{23}$ proposed an autoimmune mechanism for MG in light of the frequent co-occurrence of this disorder with other autoimmune diseases and its occurrence in the newborn. In 1966, Chang and Lee ${ }^{5}$ isolated alphabungarotoxin from snake venom and characterized their blocking actions at the neuromuscular junction. However, it was only in 1973 that Fambrough and colleagues ${ }^{12}$ and Ito and collaborators ${ }^{15}$ showed that $\mathrm{MG}$ was related to reduced number of acetylcholine receptors at the neuromuscular junction. In addition, those investigators demonstrated that low numbers of acetylcholine receptors were correlated to the reduced amplitude of the miniature endplate potentials (MEPPS). Subsequently, Vicent and Newson-Davis ${ }^{27}$ and Tzartos and colleagues ${ }^{25}$ isolated anti-acetylcholine receptor antibodies in sera of MG patients. These antibodies were of the IgG class, heterogeneous in their specificity although mostly directed against subunit alpha of the receptor. From the onwards it was clear the indication of plasmapheresis and/or immunosupression with methods of treatment of MG.

We proposed to study the effect of plasmapheresis as coadjuvant for thymectomy in MG.

\section{MATERIALS AND METHODS}

We selected 80 patients from a larger group of 286 MG patients seen at the Neurology Unit of the Hospital dos Servidores do Estado, in Rio de Janeiro. All 80 patients had a thorough clinical, laboratory and neurophysiological diagnostic assessment and were followed up a minimum of 1 year. Two groups of 40 patients, matched as well as possible for age, sex and clinical characteristics, were formed for the study.

Patients in Group 1 (15 men and 25 women) were seen among 1975 and 1983, and they were thymectomized without pre-surgery preparation. Their ages ranged from 8 to 64 years (median of 30 yrs). According to a modified Osserman's classification ${ }^{22}, 18$ patients belonged to grade IIb, 20 to grade III and 2 to grade IV.

Patients in Group 2 (17 men and 23 women) were seen among 1984 and 1993 and underwent plasmapheresis in preparation for thymectomy. Their age range was from 11 to 61 years (median of $33 \mathrm{yrs).}$ Nineteen of these patients were classified as grade IIb, 16 grade III and 5 grade IV, according to the modified Osserman's scheme referred to above.

There were no differences in sex distribution between the two groups (chi square $=0.409$, n.s.). In addition, the groups did not differ in age $(t=1.72$, n.s.) or Osserman's grades (chi square $=2.85$, n.s.). Therefore, the groups could be considered homogeneous at least for sex, age and Osserman's grades.

Muscular strength was assessed by the sworn and Lahey tests, and the determination of the opening of the palpebral fissure. In sworn test, the time the patient was able to keep the arms extended with the palms down was measured with a stopwatch. The Lahey test consisted of measuring the time the patient was able to keep one leg extended while sitting. The opening of palpebral fissure was taken as the difference in fissure after a 3 minute rest period and the size of fissure when the patient reported fatigue or the upper eyelid closed down. whichever occurred first. In addition to these tests, functional breathing tests were performed on all patients. The most sensitive measure of respiratory function in our study was maximum expiratory strength. Assessment of muscular strength and respiratory function was performed at admission and repeated immediately before and after the first session of plasmapheresis, and five days after thymectomy.

Thymectomy was performed according to accepted surgical procedures by transesternal approach and large mediastenical clearance.

\section{RESULTS}

A. Time course of the effects of plasmapheresis on muscle strength - There was a 100 to $250 \%$ (median of $202 \%$ ) and 80 to $150 \%$ (median of $130 \%$ ) increase in muscle strength after the third and fifth session of plasmapheresis, respectively, when compared to the baseline assessment. 
Table I. Use of endotracheal rube on pre and post-surgery.

\begin{tabular}{lcc}
\hline & with plasmapheresis & without plasmaferese \\
Dont use endotraqueal tube & 28 & 21 \\
Tube in pre-surgery & 9 & 2 \\
Tube in post-surgery & 3 & 17 \\
\hline
\end{tabular}

Additionally, there was a 40 to $50 \%$ (median of $43 \%$ ) amelioration of maximum respiratory strength that was related to clinical improvement and need of medication.

B. Use of endotracheal tube before and after-surgery - Table 1 shows that 9 patients in Group 2 were intubed before surgery, but all were kept free after surgery. The remaining 3 patients kept intubed after surgery were on intubation for only 8 to 12 hours after surgery. In Group 1, 2 patients were intubed before surgery and 17 were intubed also after surgery. Clearly then there were differences between the two groups in terms of need of intubation after surgery.

C. Time spent in intensive care (ICU) - Patients in Group 1 spent a mean of 10 days in ICU as compared to a mean of 12 hours for patients in Group 2.

D. Length of hospital stay - Patients in Group 1 stayed in the hospital a mean time of 65 days, whereas patients in Group 2 stayed a mean time of 42 days. Therefore, patients in latter group stayed in hospital $35.38 \%$ less time than patients in Group 1.

E. Respiratory complications - Respiratory complications (atelectasias and/or pneumonia) occurred in 13 patients in Group 1 and in none of the patients in Group 2.

F. Need of breather in the pre and post-surgery - Nineteen patients in Group 1 and seven patients in Group 2 required mechanical ventilation before surgery. However, after surgery none of the patients in Group 2 needed mechanical ventilation, whereas 17 patients in Group 1 required breathing assistance (chi square $=4.76471$ with 0 d.f.).

Table 2. Complications of plasmapheresis.

\begin{tabular}{ll}
\hline Arterial hypotension & 19 \\
Hemolysis & 8 \\
Hypothermia & 1 \\
Hypocalcemia & 8 \\
Urticaria & 4 \\
Shivers & 4 \\
Pricking & 4 \\
Trembling & 4 \\
Local catheter infection & 2 \\
Fever & 2 \\
Local haematoma & 2 \\
Transient renal insufficiency & 1 \\
\hline
\end{tabular}

G. Complications of plasmapheresis Table 2 indicates the complications observed in the present study after plasmapheresis.

Hypothermia was seen in one patient, which was immediately corrected by heating the tubes used in plasmapheresis to prevent the development of cardiac arrhythmia.

Local infection at the region of the catheter attachment was observed in two occasions and treated with antibiotics.

Arterial hypotension occurred in 19 patients, but had no clinical significance.

Other complications included hemolysis, transitory kidney insufficiency, hypocalcemia, urticaria, shrivering, fever and paresthesia.

Our data indicate that the higher cost of plasmapheresis is more than compensated for by the much shorter hospital stay required for this procedure. Therefore, we would recommend it for myasthenia gravis patients.

\section{COMMENTS}

The basic defect in MG involves an antibody-mediated autoimmune attack of neuromuscular junction that induces a decrease in the number of acetylcholine receptors at the postsynaptic site. 
The antibodies are of IgG class, have heterogeneous specificity (polyclonal) ${ }^{18,25}$ and attach to the main immunogenic region of the alpha subunit of the acetylcholine receptor ${ }^{18.22 .25 .27}$.

Since the pathogenic IgG is produced in lymphoid tissue and has to go through the circulation to reach the endplate, it can be removed by plasmapheresis. IgG is composed of two fractions: an intravascular fraction (55\% of total) and an extravascular fraction (the remaining $45 \%$ ). After a series of plasmapheresis, the intravascular fraction is rapidly withdrawn, the extravascular component passes to the intravascular space. This is followed by a progressive reduction of synthesized IgG and consequently of the extravascular fraction that probably allows for the improvement of clinical conditions $^{10,20}$. Methodological aspects of plasmapheresis such as volume withdrawn, frequency and immunoglobin synthesis are too important to consider. An immunosuppressant regimen should also be added to maintain the beneficial effects of plasmapheresis.

Plasmapheresis allows the withdrawal of approximately $88 \%$ of the antibody antireceptor of the intravascular space. After $36 \mathrm{hs}$, a new balance between the intra and extravascular sectors is established. Forty-eight hours after the new steady state is achieved, antibody levels are again $50 \%$ higher. A protocol of three sessions, one session daily, on alternate days, induces the elimination of $83 \%$ of the antireceptor antibodies. This rate of elimination allows a marked improvement in clinical conditions. Under these circumstances, surgery carries a lesser risk for the patient.

In our unit, a cost benefit analysis would favor a somewhat simplified procedure comprised of 5 sessions of plasmapheresis (one session a day on alternate days) ${ }^{16}$ with a capillary type of plasma separator, anticoagulants and a double light catheter in a deep vein (e.g., femoral), and the use of several reposition solutions (for example, Ringer-albumin, Ringer-plasma, serum-albumin, serum-plasma).

The possibility of contamination of blood derivatives by viruses (HIV, hepatitis and others) favors the use of albumin or solutions not containing blood constituents. We have been using in our unit a solution of Ringer-dextran as fluid of reposition. A study comparing several solutions is in progress and will be reported shortly.

Complications related to plasmapheresis should be immediately recognized and treated. In our experience, the most common complications were allergies, fever and hemodynamic alterations. Fever and allergy occur mostly due to the reposition fluid in the absence of corticosteroids. Citrate may induce dysesthesia and nausea when used as an anticlotting agent. Hypothermia and shivers should be immediately treated as they can cause severe cardiac arrhythmia. These two complications are more common with plasmapheresis by filtering as compared to centrifuging. It should be emphasized that all the complications we have observed were easily managed.

It is our opinion that plasmapheresis is indicated for the preparation of the patient for thymectomy. Other indications for plasmapheresis would include the rebound effects after immunosuppressors, pulmonary insufficiency and in cases where other therapies failed to improve the clinical conditions of myasthenic patient. In addition, a modified procedure could be used in neonatal MG. Compared to plasmapheresis, corticoids before thymectomy induced several complications that led to a significant prolongation of hospital stay. A detailed comparison of corticoid and plasmapheresis before thymectomy will be reported by our group.

\section{REFERENCES}

1. Appel SH, Elias SB, Chauvin P. The role of acetylcholine receptor antibodies in myasthenia gravis. Fed Proc 1979, 38: 2381-2385.

2. Barkas T, Mauron A, Roth B, Gabriel M, Tzartos S, Juillerat M, Alliod C, Ballivet M. Localization of the main immunogenic region and toxin binding site of the nicotinic acetylcholine receptor. Ann NY Acad Sci 1987, 505: 743-746. 
3. Besinger UA, Toyka KV, Homberg M. Myasthenia gravis : long term correlation of binding and bungarotoxinblocking antibodies against acetylcholine receptors with changes in disease severity. Neurology 1983. 33:1316-1321.

4. Campbell H, Bramwell E. Myatenia gravis . Brain 1900, 23: 277-336.

5. Chang CC, Lee CY. Electrophysiological study of neuromuscular blocking action of cobra neurotoxin. Br $\mathrm{J}$ Pharmacol Chemother 1966, 28: 172-181.

6. Chang CE, Lee CY. Isolation of neurotoxins from the venom of Bungarus multicinctus and their mode of neuromuscular blocking action. Arch Int Pharmacodyn Ther 1962, 144:241-257.

7. Cohen MS, Younger D. Aspects of the natural history of myasthenia gravis. Ann NY Acad Sci 1981, 377 : 670-677.

8. Compston DAS, Vicent A, Newson-Davis J. Clínical, pathological, HLA antigen and immununological evidence for disease heterogeneity in myathenia gravis. Brain 1980,103: 579-601.

9. Dalakas MC, Rose JW, Paul J. Increased circulation of T lymphocytes bearing surface thymosin-a $I$ in patients with myasthenia gravis : effects of thymectomy. Neurology 1983, 34: 144-149.

10. Dau PC, Lindstrom J, Cassel CK. Plasmapheresis and immunosuppressive therapy in myasthenia gravis . N Eng J Med 1977, 297: 1134-1140.

11. Engel AG, Sahashi K, Fumagalli G. The immunopathology of acquired myasthenia gravis. Ann NY Acad Sci 1981, 377: 158-174.

12. Fambrough DM, Drachman DB, Satyamurti $S$. Neuromuscular junction in myasthenia gravis: decreased acetylcholine receptors. Science 1973, 182:293-295.

13. Garlepp MJ, Kay PH, Dawkins RL. The diagnostic significance of autoantibodies to acetylcholine receptor. J Neuroimmunol 1982, 3:337-360.

14. Greer M, Schotland M. Myasthenia gravis in the newborn. Pediatrics 1960, 26: 101-108.

15. Ito $Y$, Miledi R, Vicent A, Newson-Davis J. Acetylcholine receptor $s$ and endplate electrophysiology in myasthenia gravis . Brain 1978, 101: 345-368.

16. Seggia JCB, Abreu P. Plasmaferese em neurologia: análise crítica da indicação e protocolos. Arq Neuropsiquiatr 1992, 50: 324-328.

17. Keesey J, Buffkin D, Kebs D. Plasma exchange alone as therapy for myasthenia gravis .Ann NY Acad Sci 1981, 377: 729-743.

18. Lefvert AK. The human acetylcholine receptor antibody : studies of kinetic proprieties and the reaction with antiidiotypic antibodies. Ann NY Acad Sci 1981, 377: 125-142.

19. Newson-Davis J, Wilson SG, Vicent A. Long term effects of repeated plasma exchange in myasthenia gravis . Lancet 1979, 1: 464:-468.

20. Olarte MR, Schoenfeldt RS, Penn AS.. Effect of plasmapheresis in mysthenia gravis, 1978-1980. Ann NY Acad Sci 1981, 377:725-728.

21. Oppenheim H. Zur myastheniche Paralyse. Berlin: Karger, 1901.

22. Osserman KF, Genkins G. Studies in myasthenia gravis : review of a twenty year experience in over 1200 patients. Mt Sinai J Med 1961, 38: 197.

23. Simpson JA.. Myasthenia gravis: a new hypothesis . Scott Med J 1960, 4:419-436.

24. Tindall RSA. Humoral immunity in myasthenia gravis : biochemical characterization of acquired antireceptor antibodies and clínical correlations. Ann Neurol 1981, 10: 437-447.

25. Tzartos SJ, Seybold ME, Lindstrom JM. Specificities of antibodies to acetylcholine receptors in sera from myasthenia gravis patients measured by monoclonal antibodies. Proc Nat Acad Sci, USA 1982, 79:188-192.

26. Vicent A, Newson-Davis J. Acetylcholine receptor antibody characteristics in myasthenia gravis: I. Patients with generalized myasthenia or disease restricted to ocular muscles. Clin Exp Immunol 1982, 49: 257-265.

27. Vicent A, Newson-Davis J. Anti-acethylcholine receptors antibodies . J Neurol Neurosurg Psychiatry 1980, 43: $590-600$. 